\title{
MONTANA PRAIRIE DOG MANAGEMENT GUIDELINES
}

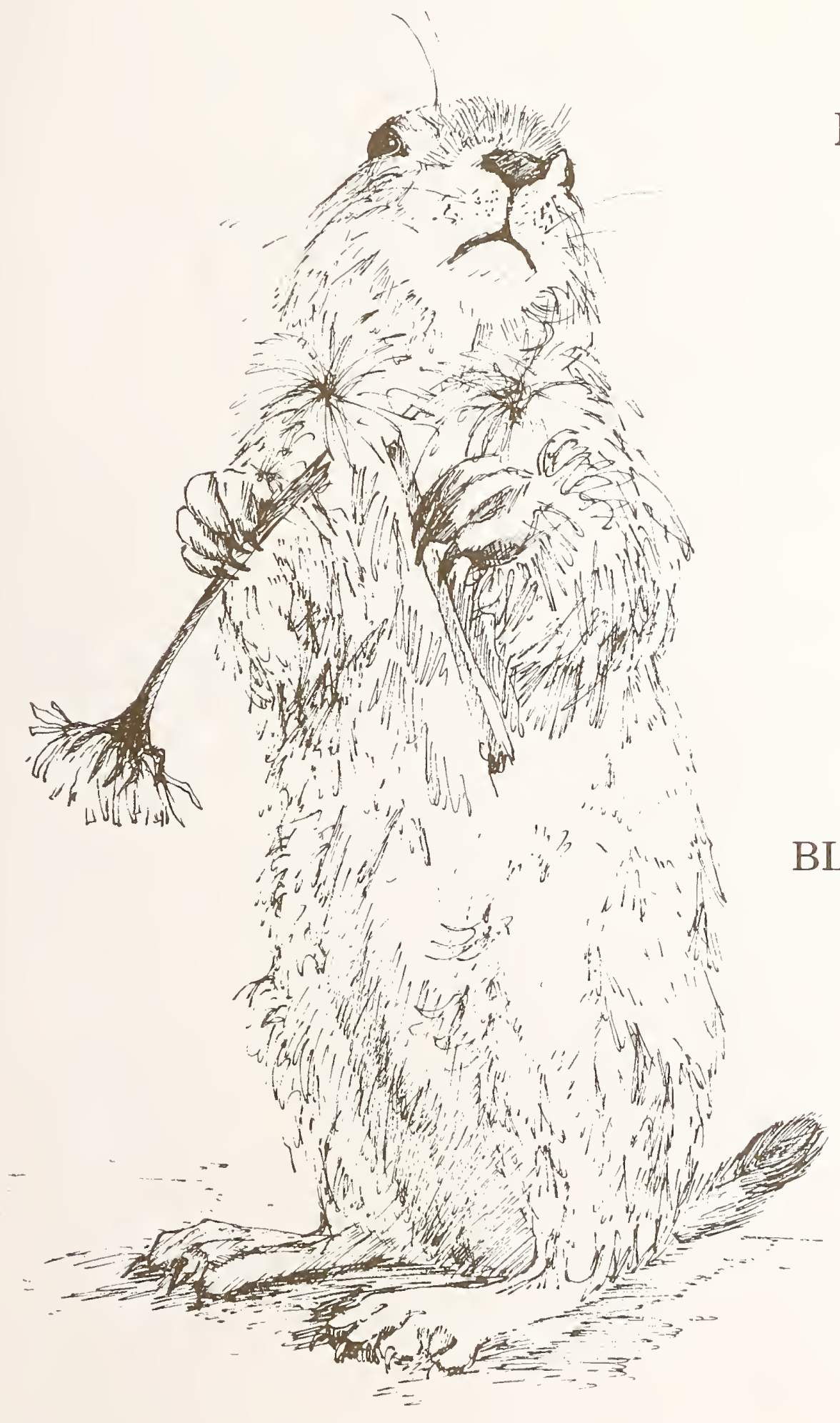

MAY 1988

prepared by:

$\checkmark$ MONTANA

BLACK-FOOTED FERRET

WORKING GROUP 


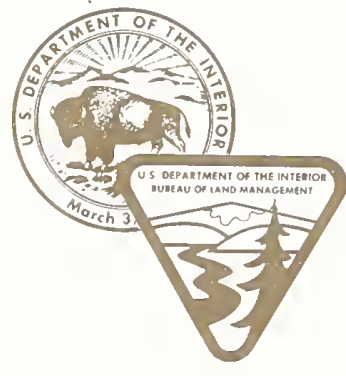

\section{Printed by \\ Department of the Interior Bureau of Land Management Montana State Office} Copies may be obtained from the Montana State Office, Bureau of Land Management, P.O. Box 36800, Billings, Montana 59107 while supplies last.

\footnotetext{
As the Nation's principal conservation agency, the Department of the Interior has responsibility for most of our nationally owned public lands and natural resources. This includes fostering the wisest use of our land and water resources, protecting our fish and wildlife, preserving the environmental and cultural values of our national parks and historical places, and providing for the enjoyment of life through outdoor recreation. The Department assesses our energy and mineral resources and works to assure that their development is in the best interests of all our people. The Department also has a major responsibility for American Indian reservation communities and for people who live in Island Territories under U.S. administration.
} 
These Montana Prairie Dog Management Guidelines are approved:

sam in thy m

James F yon, Director

Montane Department of Fish, Wildlife and Parks
$5 / 24 / 88$

Date

JUNE 3,1988

Date

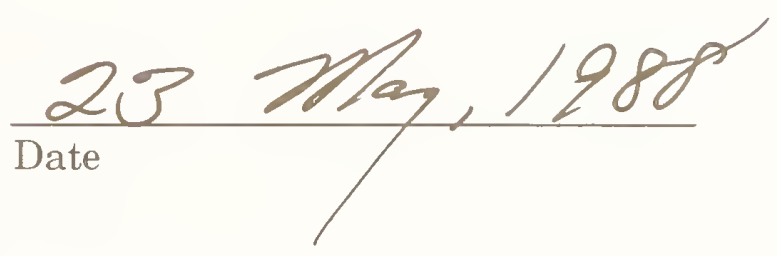

$6 / 16 / 88$

Date

May der, 1988

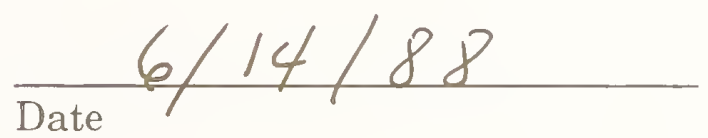

Date

$$
5-23-88
$$

Date

Animal and Plant Health Yhspection Service 
Digitized by the Internet Archive in 2016 


\section{CONTENTS}

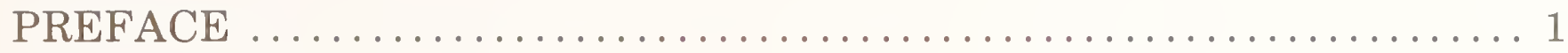

PRAIRIE DOG MANAGEMENT GUIDELINES $\ldots \ldots \ldots \ldots \ldots \ldots \ldots$

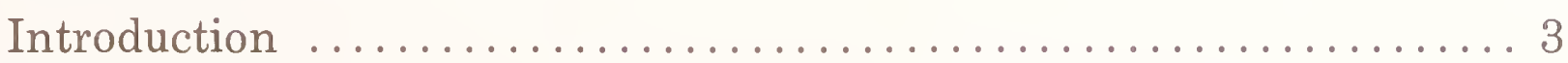

Goals of the Guidelines ............................... 4

Management Objectives and Guidelines $\ldots \ldots \ldots \ldots \ldots \ldots \ldots \ldots . \ldots$

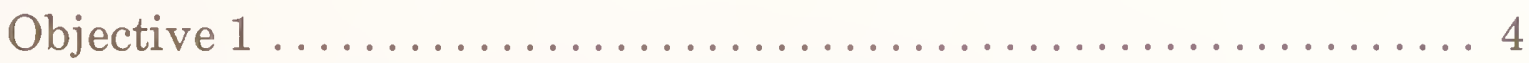

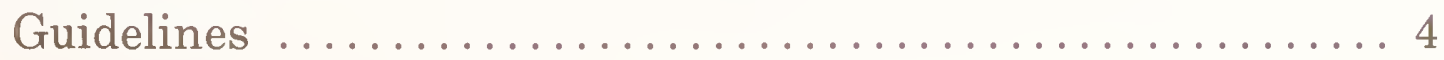

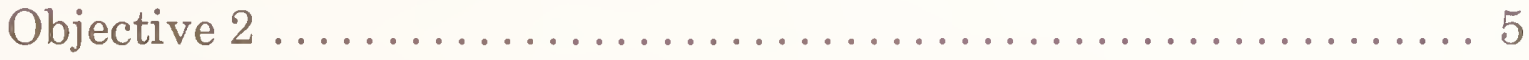

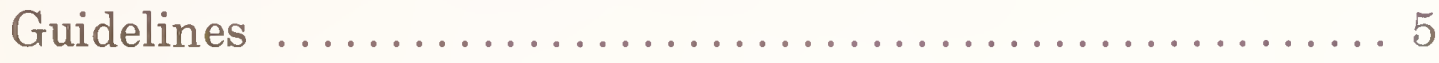

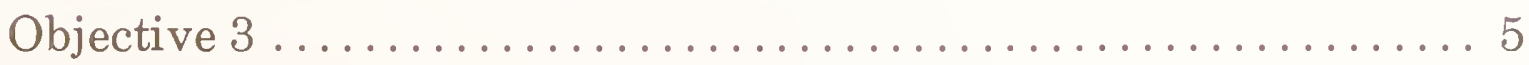

Guidelines ................................. 5

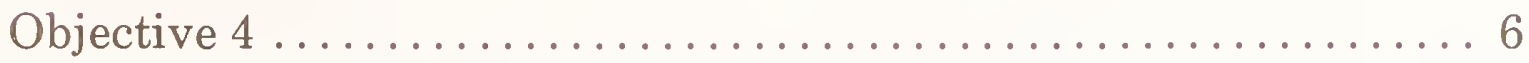

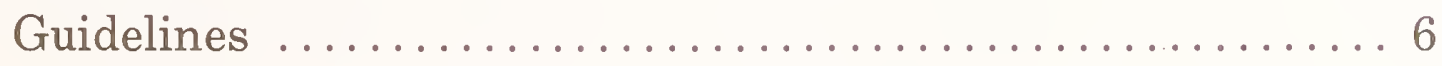

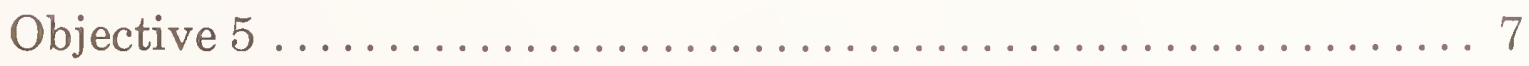

Guidelines ................................ 7

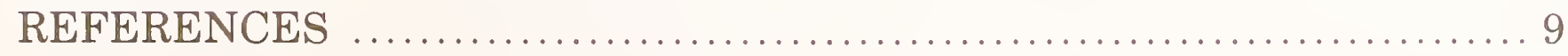

APPENDIX - Site Specific Prairie Dog Management Plan ........... 11 
. 


\section{PREFACE}

These guidelines were developed by a working group of individuals representing State and Federal agencies and private interests that are concerned about and responsible for black-footed ferret and prairie dog management in Montana. Since 1984, the group has met two or more times each year to share information and discuss recommendations for recovery of the black-footed ferret and management of prairie dogs. Products of the group include: (1) "Analysis of Black-Footed Ferret Translocation Sites in Montana” (Clark et al. 1987); (2) “Annotated Prairie Dog Bibliography - 1973 to 1985" (Clark 1986a); (3) “WANTED: The Masked Stranger” (Flath 1987); and (4) these guidelines.

While a mutual concern to maintain recovery options for black-footed ferrets served as a catalyst for this group, it was recognized that long-term management of the prairie dog ecosystem would impact far more than a single species. Strategies for prairie dog management must address human social and economic issues as well as the biological needs of wildlife and plant species. Therefore, it is imperative that prairie dog management be addressed directly, regardless of the outcome of black-footed ferret recovery efforts.

These guidelines were developed to provide land managers with reasonable and uniform guidance for prairie dog management and protection of natural resources essential to the maintenance of prairie dog ecosystems in Montana. The guidelines are flexible enough to accommodate changes in National and State priorities and changes in the status of prairie dogs in Montana, yet remain adequate to accomplish stated goals and objectives.

THIS DOCUMENT DOES NOT SUPERSEDE EXISTING AGREEMENTS OR MODIFY ANY AGENCY RESPONSIBILITIES.

Persons involved in the development of the guidelines include:

Thomas Campbell III

Biota Research and Consulting, Inc.

Tim Clark

Biota Research and Consulting, Inc. and

Northern Rockies Conservation Cooperative

Monty Sullins

Montana Department of Agriculture

Dan Sullivan

Montana Department of Agriculture

John Cada

Montana Department of Fish, Wildlife \& Parks

Arnold Dood

Montana Department of Fish, Wildlife \& Parks

Dennis Flath

Montana Department of Fish, Wildlife \& Parks

Dave Smith

U.S. Bureau of Indian Affairs

Greg Smitman

U.S. Bureau of Indian Affairs
Bob Swick

U.S. Bureau of Indian Affairs

Dan Bricco

U.S. Bureau of Land Management

Mark Gorges

U.S. Bureau of Land Management

John Grensten

U.S. Bureau of Land Management

Dan Hinckley

U.S. Bureau of Land Management

Terry Rich

U.S. Bureau of Land Management

Ron Crete

U.S. Fish and Wildlife Service

Bill Haglan

U.S. Fish and Wildlife Service

John Edwards

U.S. Forest Service 


\section{PRAIRIE DOG MANAGEMENT GUIDELINES}

\section{Introduction}

Two species of prairie dogs occur in Montana; the black-tailed prairie dog (Cynomys ludovicianus) which occurs in non-alpine grasslands east of the continental divide and the white-tailed prairie dog (Cynomys leucurus) which is found only in southern Carbon County.

An active prairie dog colony is any assemblage of reproducing prairie dogs and their burrows. Colonies are considered "inactive" when no prairie dogs are present. Clusters of prairie dog colonies are called "prairie dog complexes." Prairie dog colonies and complexes host many vertebrate and invertebrate species. Some, such as the black-footed ferret (Mustela nigripes), are directly dependent on prairie dogs (Clark et al. 1982) while others, such as mountain plovers (Charadrius montanus), burrowing owls (Athene cunicularia), and swift fox (Vulpes velox) are indirectly dependent (Campbell and Clark 1981). The inter-relationship of plant life, animal life, and the abiotic components of of prairie dog colonies and complexes is the prairie dog ecosystem. Prairie dog ecosystems may vary in size and include one or more prairie dog colonies or complexes.

The ecology of prairie habitats in North America has been significantly altered over the past century, and prairie dog ecosystems have been particularly affected by extensive poisoning and agricultural practices. Consequently, much of the prairie dog's former range has been drastically reduced and, in some cases, totally eliminated. Many species of wildlife dependent on prairie dogs or their habitat have been affected accordingly.

Prairie dog ecosystems are not a static assemblage of plants and animals but rather, profoundly dynamic. This fact challenges land managers and administrators who must strive to ensure that neither prairie dogs nor species associated with them become endangered or extinct. This challenge is complicated by the coexistence of prairie dogs and livestock on grasslands. Hence, public land managers must establish policy and guidelines that protect the inherent scientific, educational, and ecological values of prairie dog ecosystems while accommodating other legitimate land uses. These guidelines are provided to assist land managers in meeting this challenge. 


\section{Goals of the Guidelines}

1. Inform public and private land managers in Montana of the role of the prairie dog ecosystem.

2. Assist land managers in developing long-term management objectives for prairie dog ecosystems including those for associated species that may be threatened, endangered, or of special concern.

3. Help managers identify potential problems for prairie dog populations in Montana and offer recommendations to avoid or resolve conflicts.

4. Ensure that managers consider the biology and needs of associated species in developing prairie dog management plans.

5. Establish a framework for a reliable prairie dog ecosystem and associated species management protocol for land management agencies, wildlife agencies, and private landowners.

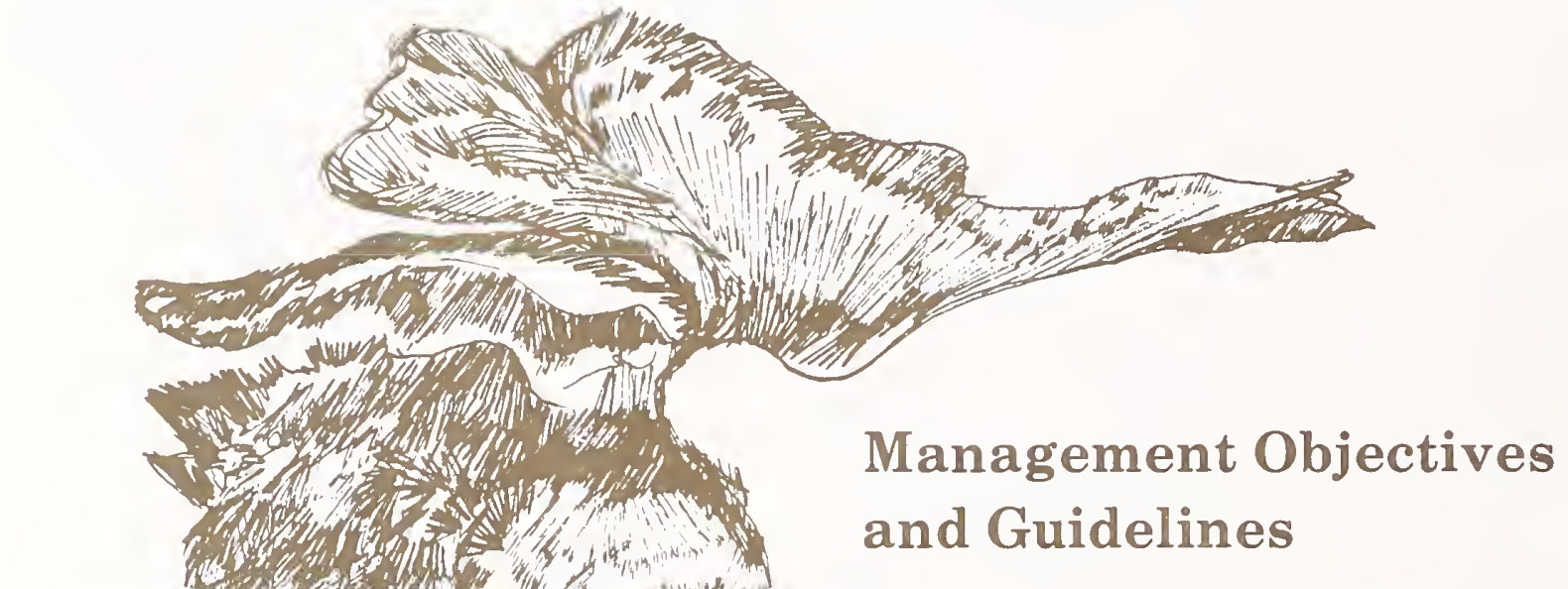

Objective 1:

Develop understanding, interest, and support for management of prairie dog ecosystems in Montana.

Guidelines:

1. Land managers and the public should understand the role of the prairie dog in Montana's natural history, and citizens should be encouraged to participate in establishing management priorities for prairie dog ecosystems in the state.

2. The public's interest, understanding, and knowledge of the prairie dog ecosystem and its economic importance in Montana should be determined.

3. Consumptive and non-consumptive uses of prairie dog ecosystems within established management plans should be presented in public information programs.

4. Booklets and posters about the prairie dog ecosystem should be developed for use in elementary and agriculture curricula. These should be distributed to specific groups and made available to the general public. 


\section{Objective 2:}

Maintain prairie dog ecosystems to ensure adequate habitats for the continued existence of threatened, endangered, and associated species.

\section{Guidelines:}

1. Ensure that high quality habitat is managed to prevent irreversible declines in endangered and threatened species, and species of special concern, including: black-footed ferret, swift fox, ferruginous hawk (Buteo regalis), golden eagle (Aquila chrysaetos), mountain plover and burrowing owl. For example, recovery of the black-footed ferret requires the establishment of several secure ferret populations throughout its potential range. Thus, identifying, evaluating, and managing prairie dog complexes for reintroduction of ferrets in Montana is necessary for recovery of this endangered species. Habitat management guidelines for the black-footed ferret have been published (Forrest et al. 1985) and should be referred to when developing management and reintroduction plans for ferrets.

2. Many other species of wildlife occur in close association with prairie dogs. In striving for stable ecosystems, managers should maintain habitat to ensure the functional role of each species within that ecosystem.

\section{Objective 3:}

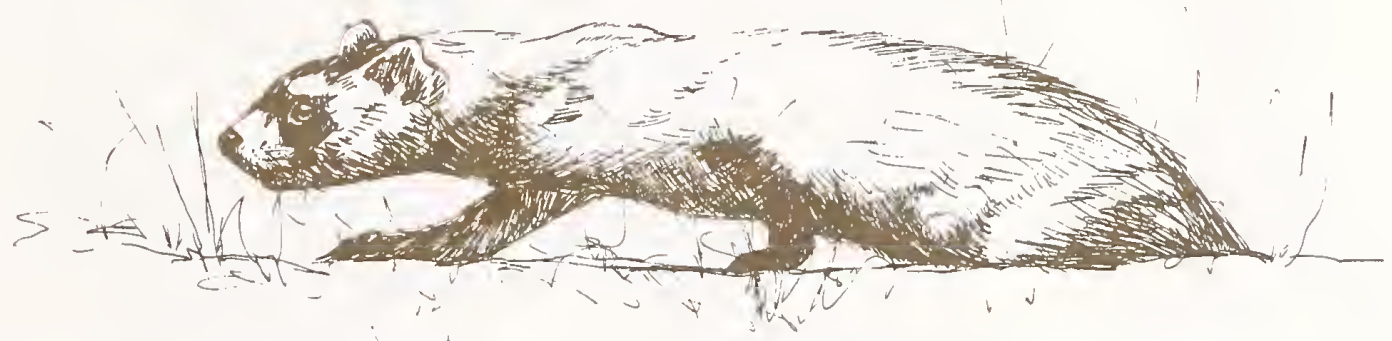

Identify standards and techniques for managing prairie dog populations in Montana.

\section{Guidelines:}

1. Develop site-specific prairie dog management plans wherever an intentional change in distribution or abundance of prairie dogs is proposed. Such actions may vary from extensive management plans on public lands to private landowner decisions. This could include actions to maintain, eliminate, or increase the size of prairie dog colonies. Recommended procedures for developing these plans are contained in Appendix I which also has a planning and action matrix to be used for selecting specific management techniques, based upon associate species and conflict value ratings.

2. When management objectives involve the use of rodenticides to reduce or eliminate prairie dogs, only recommended methods and materials registered by the Environmental Protection Agency and the Montana Department of Agriculture (MDA) can be used. Acceptable methods, materials, recommendations and use restrictions may change. Therefore, periodic contacts with the MDA or U.S. Department of Agriculture, Animal and Plant Health Inspection Service must be made. Management techniques for grazing, range improvements, and sport shooting should also be integrated into a prescription for prairie dog management.

3. Public land managers should establish cooperative prairie dog management programs with private landowners or lessees. This is particularly important where prairie dogs inhabit public lands immediately adjacent to privately-owned lands. 


\section{Objective 4:}

Monitor prairie dog ecosystems to determine the status and trend of populations of prairie dogs, threatened and endangered species, and species of special concern.

\section{Guidelines:}

1. Prairie dog colonies that constitute potential or known habitats for threatened or endangered species or species of special concern should be identified, mapped, and monitored. Monitoring plans should be implemented and revised as needed or at least every 5 years. Accurate records should be maintained for each colony.

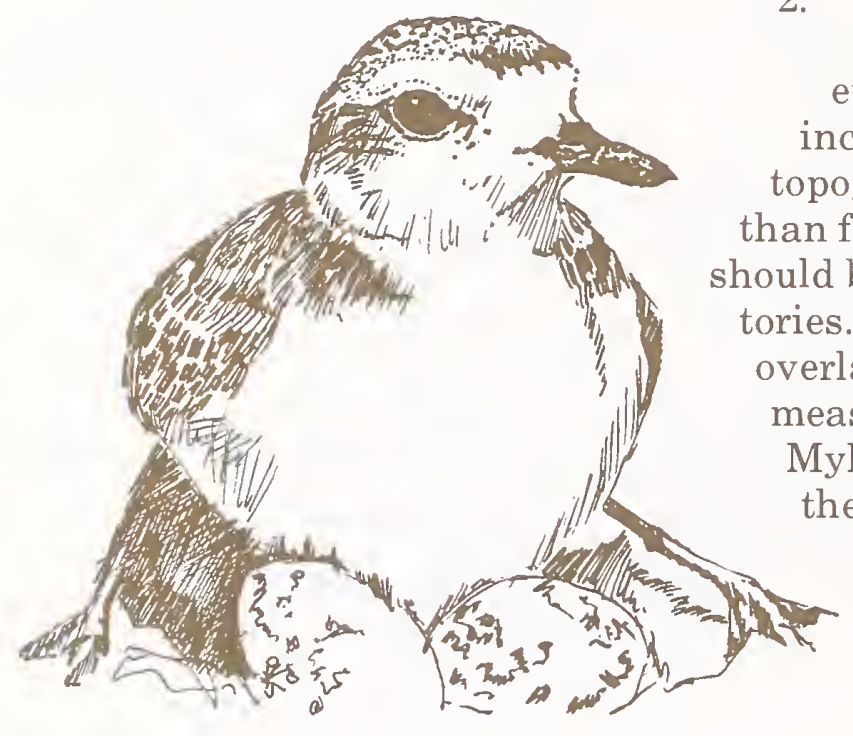

2. Prairie dog colonies containing greater than or equal to 4 burrows per acre, should be mapped at least once every 5 years on overlays of aerial photos (minimum 2 inch to the mile) or U.S. Geological Survey 7.5-minute topographic maps. Areas containing colonies with less han four burrows per acre are generally difficult to map and ould be labeled as "scattered" for future reference or invenries. Initial and follow-up mapping should be done on verlays of the same map or photo which can then be measured to monitor changes in size (see Schenbeck and Myhre 1986). Follow-up mapping should be conducted at the same time of year as initial mapping efforts. When a colony is poisoned or abandoned as a result of natural causes (e.g., plague), it is very important that this information be retained for historical purposes. A yearly summary of field efforts should also be prepared.

3. The status of threatened or endangered species inhabiting prairie dog colonies should be documented annually. Monitoring plans should be developed for colonies occupied by black-footed ferrets and should follow "Handbook of Methods for Locating Black-footed Ferrets" (Clark et al. 1984). If other species associated with prairie dog colonies are identified as threatened or endangered in the future, the monitoring procedures for those species should be established accordingly.

4. Species of special concern should be monitored at least every 5 years. Situations will vary at different locations and with different species, thus systematic sampling methods should be devised for each species as needed. One method would be a system of linear transects 50 to 75 feet apart covering 100 percent of each colony.

5. All other prairie dog colonies should be located and periodically assessed to determine their status and trends.

6. Factors influencing the survival and dynamics of prairie dog colonies and complexes of colonies should be identified. 


\section{Objective 5:}

Design research to find solutions to short and long-term biological and social problems related to prairie dog ecosystem management.

\section{Guideline:}

1. Identify prairie dog research needs and priorities in Montana. This may include basic or applied research. Monitoring methodologies are also needed to test the effectiveness of management actions.

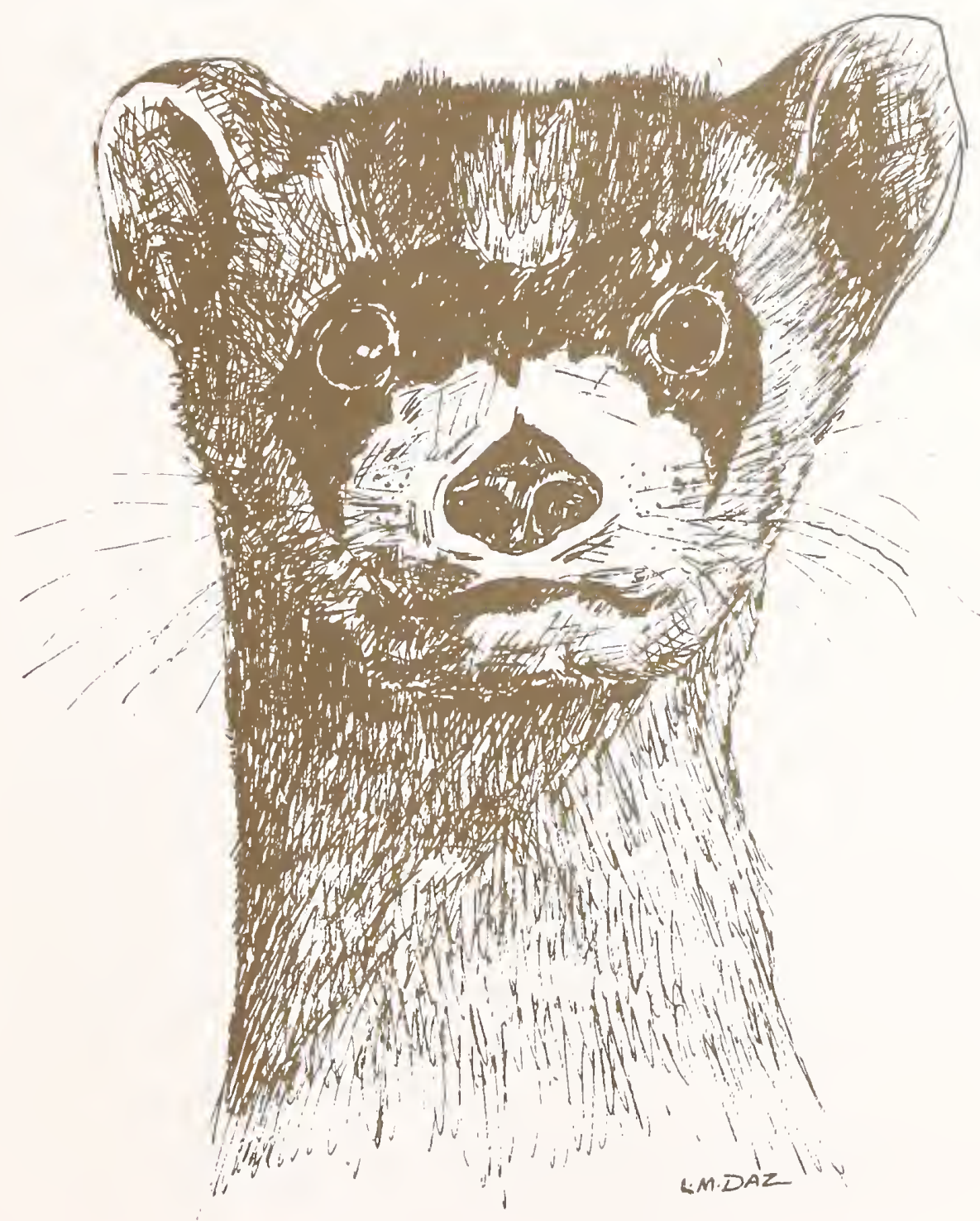




\section{REFERENCES}

Black-Footed Ferret Recovery Team. 1978. Black-footed ferret recovery plan. USDI, USFWS, Denver, CO. $150 \mathrm{pp}$.

Bredy, J., and S. Coy. 1981. The use of infrared photography in locating and mapping white-tailed prairie dog (Cynomys leucurus) colonies as potential habitat for black-footed ferrets (Mustela nigripes) in northwest Wyoming. Cody. 30 pp.

Bureau of Land Management. 1982. Black-tailed prairie dog: Control/management in Phillips Resource Area. Programmatic Environmental Assessment. Bureau of Land Management, Malta, MT. 40 pp. + appendices.

Campbell, T.M., III, and T.W. Clark, 1981. Colony characteristics and vertebrate associates of white-tailed and black-tailed prairie dogs in Wyoming. Amer. Midland Nat. 105(2):269-275.

Clark, T. W. 1971. Towards a literature review of prairie dogs. Wyoming J. Range Manage. 236:29-44. 1986a. Annotated prairie dog bibliography 1973 to 1985. Montana BLM Wildl. Tech. Bull. No. 1. Billings. $32 \mathrm{pp}$.

1986b. Some guidelines for management of the black-footed ferret. Great Basin Nat. Mem. 8:160-168.

T. M. Campbell III, D. C. Socha, and D. E. Casey. 1982. Prairie dog colony attributes and associated vertebrate species. Great Basin Nat. Mem. 42:572-582.

T. M. Campbell III, M.H. Schroeder, and L. Richardson. 1984. Handbook of Methods for Locating Black-Footed Ferrets. Wyoming BLM Wildlife Tech. Bull. No. 1. Cheyenne. 55 pp.

J. Grensten, M. Gorges, R. Crete, and J. Gill. 1987. Analysis of black-footed ferret translocation sites in Montana. Prairie Nat. 19 (1):43-56.

Flath, D. L. 1984. Vertebrate species of special interest or concern. Montana Dept. of Fish, Wildlife \& Parks, Helena. 76 pp.

1987. WANTED: The masked stranger. Montana Outdoors 18(4):18-22.

and T. W. Clark. 1986. Historic status of black-footed ferret habitat in Montana. Great Basin Nat. Mem. 8:63-71.

Forrest, S.C., T.W. Clark, L. Richardson, and T.M. Campbell III. 1985. Black-footed ferret habitat: Some management and reintroduction considerations. Wyoming BLM Wildl. Tech. Bull. No. 2. Cheyenne. 49 pp.

Forrest, S. C., T. W. Clark, L. Richardson, D. Biggins, K. A. Fagerstone, and T. M. Campbell III. 1985. Life history characteristics of the genus Mustela, with special reference to the black-footed ferret Mustela nigripes. In S. H. Anderson and D. B. Inkley, (eds). Black-Footed Ferret Workshop Proc., Sep. 18-19, 1984. Wyo. Game \& Fish Dept., Laramie. Pp. 23.1-23.14.

Hassein, F. 1973. Prairie dog bibliography. U.S. Dept. of Interior, BLM, Tech. Note 279. 28 pp.

Houston, B., T. W. Clark, and S. C. Minta. 1986. Habitat suitability index model for the black-footed ferret: A method to locate transplant sites. Great Basin Nat. Mem. 8:99-114.

Maguire, L. A., T. W. Clark, R. Crete, J. Cada, C. Groves, M. Shaffer, and U. Seal. In Press. Black-footed ferret recovery in Montana: A decision analysis. 20 pp.

Schenbeck, G. L. and R. J. Myhre. 1986. Aerial photography for assessment of black-tailed prairie dog management on the Buffalo Gap National Grassland, South Dakota. 15 pp. 


\section{APPENDIX \\ SITE-SPECIFIC PRAIRIE DOG \\ MANAGEMENT PLAN}

\section{Introduction}

Include any special background information as a basis for the management plan, particularly how it relates to existing land use plans. Identify the source of information used to develop the plan and the extent of site-specific prairie dog information. Identify the agencies and administrative units responsible for implementing the plan. Establish monitoring methods and schedules to evaluate the effectiveness of the plan.

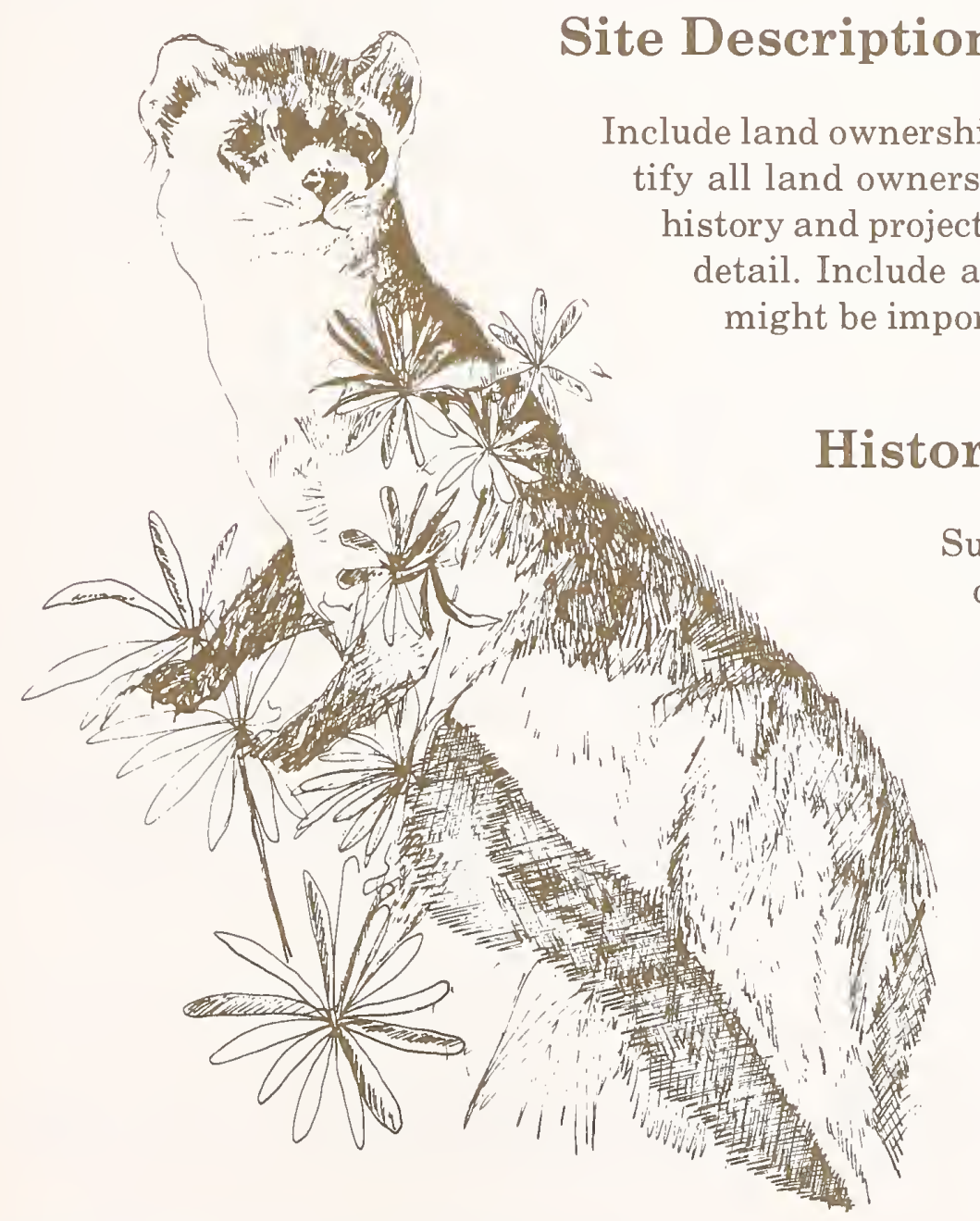

Summarize what is known about prairie dog occurrence in the planning area. Include documented historical prairie dog colonies, control chronology and history.

\section{Potential Conflicts}

Identify and discuss management problems and potential conflicts for prairie dogs in the planning area.

\section{Management Areas}

Describe the occupied and potential range of prairie dogs in the planning area. Include a detailed map. 


\section{Situation Analysis}

A. Describe Site Specific management objectives

B. Describe and analyze management options.

C. Identify and define variables used. An actual list of variables used on a test area follows. It will be necessary to consider different variables for each situation.

1. Colony size

2. Change in colony size

3. Number of species of special concern present

4. Unique attributes; largest town, snake den, mountain plover staging area, burrowing owl concentration, raptor staging area

5. Management treatments to date. See Planning and Action Matrix at the end of this document.

6. Years in shooting program

7. Existing developments; public road, windmill, stock pond, fish pond, oil well, Ducks - Unlimited project, land exchange, air strip

8. Proposed development

9. Estimated rebound time.

10. Nearest neighbor colony

11. Number of colonies within 4 miles.

\section{Management Direction}

1. If existing information is inadequate to proceed with management recommendations, identify assumptions to replace information needs or gather the needed information.

2. Identify specific management direction for the planning area or specific sites and how that direction was selected. A planning/action matrix is provided at the end of this document to assist in this task.

\section{Future Action Items}

Identify what is needed for future management such as research, monitoring, habitat improvement, prioritization of land use, or a change in livestock stocking rates. Set preliminary time frames, budgets, and schedules.

\section{Literature Cited}

In addition to published information, cite file data, personal communications, and other sources of information. 
RECOMMENDED STEPS FOR DEVELOPING SITE-SPECIFIC

\section{MANAGEMENT PLANS}

\section{Recommended Steps}

1. Document current and historical use of area by prairie dogs

2. Document habitat conditions of recent populations

3. Delineate boundaries for site-specific plan

4. Evaluate associate species

5. Identify existing and potential developments within area

6. Identify factors which influence vegetative productivity and ecological condition

7. Inventory recreation use levels.

8. Identify landowners and include them in all management considerations

9. Develop specific management objectives for area

10. Provide recommendations to accomplish recreation objectives

11. Provide site-specific recommendations for protection and enhancement of threatened and endangered species or species of special concern

12. Provide recommendations on prairie dog expansion area

13. Provide recommendations on prairie dog control areas

14. Review site specific plans with black-footed ferret working group when appropriate

15. Submit plan for approval and implementation

16. Describe methods to monitor and evaluate plan

\section{Management Concerns}
a. Past acreage
b. Current acreage
c. Potential acreage
a. Other resource uses
b. Vegetative succession
c. Habitat alterations past and planned for future
d. Control actions
a. Current occupied area
b. Potential occupied area
c. Number of prairie dog colonies
a. Identify associate species occurrence
b. Determine ecological relationships
c. Map habitat areas and seasonal use patterns
a. Water developments, salt stations, roads, fences, corrals and others
a. Quality of prairie dog habitat

a. Developed recreational sites, campgrounds, special uses

b. Dispersed recreation, road systems
a. Designated shooting areas
b. Location of access and development
c. Necessary closures
d. Signing

Priorities for selection:
a. High associate species rating
b. High potential conflict ratings
c. Any new activities or status change in primary areas

a. Alternate colony establishment area in the event large areas of prairie dogs are wiped out by disease or other natural disaster

a. Prairie dogs expand beyond desired level

b. Identify preferred techniques

a. The working group will review plan for adequacy and interpretation of data

b. Management recommendations will be evaluated and/or provided

a. Establish time frames for evaluating the plan and specific management actions 


\section{PLANNING AND ACTION MATRIX FOR PRAIRIE DOG MANAGEMENT}

The planning and action matrix is designed to provide guidance in selecting the most appropriate techniques for prairie dog management.

Development of a site-specific management plan is a logical first step prior to implementing management actions. For prairie dogs, the term

"site-specific" is a bit problematic. In present context it means a given prairie dog colony or complex which constitutes a logical grouping. A "site", for example, could also be considered as equivalent to a given grazing allotment.

Associate species values are identified as A-1, A-2, A-3, A-4. Conflict values are identified as C-1, C-2, and C-3. The screened blocks represent the need to develop and possibly implement a site-specific management plan.
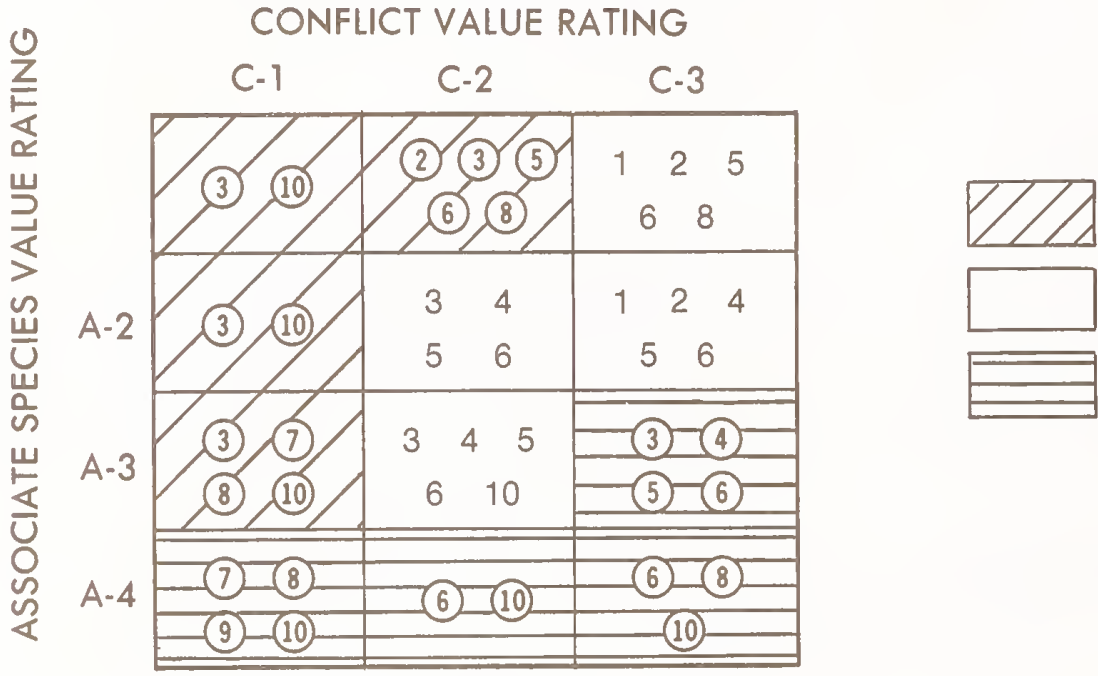

Planning desirable but not necessary

Planning important and should be pursued if management is needed

Planning imperative and should have a high priority

\section{SPECIFIC TECHNIQUES:}

1. Complete elimination of the prairie dog town with toxicants, including necessary follow-up.

2. Complete control, short of elimination, of the prairie dog town no follow-up.

3. Density reduction through a directed shooting program.

4. Periphery control or fragmentation of large towns or elimination (techniques \#1) of some towns in a complex using toxicants.

5. Chisel plowing, scarifying, planting. Used in conjunction with Technique \#2 or \#4.

6. Reduce grazing pressure. Additional fencing or fewer AUMs may be necessary.

7. Increase grazing pressure. Additional development or increased AUMs may be necessary.

8. Manipulate grazing pressure through strategic salt and water placement.

9. Controlled burning can be used to increase potential for prairie dog expansion.

10. No action. Just leave it alone.

The manager has the option of ultimately using any technique on any prairie dog colony over which he has authority. However, the matrix identifies those techniques which logically seem the most appropriate. These should be identified and considered in the "Management Direction" portion of the Site-Specific Plan. The manager should avail himself of the opportunity to use one or any combination of appropriate techniques for management. The Site-Specific Plan becomes a written record of the manager's decision, the options considered, and why the implemented action was selected.

\section{ASSOCIATE SPECIES VALUE RATING}

A- 1 ISOLATED PRAIRIE DOG COLONY.

Not within 4 miles of another prairie dog colony. No particular associate species values or unique ecological relationships are present. Endangered or threatened species and species of special concern are absent or clearly nondependent.

\section{A-2 PRAIRIE DOG COLONY/COMPLEX IS AN ELEMENT OF A LARGER PRAIRIE DOG COMPLEX.}

No particular associate species values or unique ecological relationships are present. Endangered or threatened species and species of special concern are absent or clearly non-dependent.

A-3 PRAIRIE DOG COLONY IS NOT AN ELEMENT OF A LARGER PRAIRIE DOG COMPLEX, OR, ASSOCIATE SPECIES VALUES OR UNIQUE ECOLOGICAL RELATIONSHIPS ARE PRESENT. Endangered or threatened species are absent, but at least one species of special concern is present and exhibits a clear degree of dependency.

A-4 PRAIRIE DOG COLONY CLEARLY EXHIBITS ASSOCIATE SPECIES VALUES OR UNIQUE ECOLOGICAL VALUES. Endangered or threatened species are present, or, three or more species of special concern are present and exhibit a clear degree of dependency.

\section{CONFLICT VALUE RATING}

C-1 Prairie dog colony/complex has NOT BEEN the source of land owner/lessee complaints. Opportunities for expansion to adjacent land ownership is minimal or absent.

C-2 Prairie dog colony/complex has NOT BEEN the source of landowner/lessee complaints from more than one source. However, opportunities to expand to adjacent land ownerships which could result in severe complaints are clearly present.

C-3 Prairie dog colony/complex HAS BEEN the source of landowner/lessee complaint from two or more sources. Expansion to adjacent lands is imminent. 


